\title{
The foraging activity of bats in managed pine forests of different ages
}

\author{
Andrzej Węgiel ${ }^{1}\left[\right.$ D Witold Grzywiński ${ }^{1} \cdot$ Mateusz Ciechanowski ${ }^{2} \cdot$ Radosław Jaros $^{3} \cdot$ Matina Kalcounis-Rüppell $^{4}$. \\ Anna Kmiecik $^{5}$ - Paweł Kmiecik ${ }^{6}$. Jolanta Węgiel ${ }^{1}$
}

Received: 1 September 2017 / Revised: 16 December 2018 / Accepted: 31 January 2019 / Published online: 9 March 2019 (c) The Author(s) 2019

\begin{abstract}
Temperate zone bats are associated with forests and affected by forest management practices. However, practices vary among regions and countries, and the relationship between bats and managed forest stands is not well understood. We compared the activity of bats in three forest management areas across four stand ages of managed Scots pine (Pinus sylvestris) in western Poland. Stand ages included clear-cut stands, young (2-5 year) stands, middle-aged (41-60 year) stands, and mature ( $>80$ years) stands. We sampled bat activity by walking transects with a broadband ultrasound Pettersson D-1000X detector. Across our study area, highest bat activity was in clear-cut and young stands and lowest in mature stands. Bat species adapted to foraging in open habitats had high activity in clear and young stands, while those adapted to closed habitats had high activity in middle-aged and mature stands. Our results suggest that the presence of mature pine forests is important for closed-habitat foragers, including rare and threatened bat species, and active management to increase mature forest areas is important. At the same time, a mosaic of different growth stages of stands can support high activity of open- and edgehabitat foragers.
\end{abstract}

Keywords Chiroptera $\cdot$ Commuting $\cdot$ Diversity $\cdot$ Foraging $\cdot$ Forest management $\cdot$ Pinus sylvestris

Communicated by Gediminas Brazaitis.

Electronic supplementary material The online version of this article (https://doi.org/10.1007/s10342-019-01174-6) contains supplementary material, which is available to authorized users.

Andrzej Węgiel

wegiel@up.poznan.pl

1 Faculty of Forestry, Poznań University of Life Sciences, Wojska Polskiego 28, 60-637 Poznań, Poland

2 Faculty of Biology, University of Gdańsk, Wita Stwosza 59, 80-308 Gdańsk, Poland

3 The Polish Society for Nature Conservation "Salamandra", Stolarska 7/3, 60-788 Poznan, Poland

4 Department of Biology, University of North Carolina at Greensboro, PO Box 26170, Greensboro, NC 27412-5000, USA

5 Forest District Lądek Zdrój, Strachocin 42, 57-550 Strachocin, Poland

6 Forest District Międzylesie, Tysiąclecia Państwa Polskiego 7, 57-530 Międzylesie, Poland

\section{Introduction}

Temperate coniferous forest is the main forest type in the Northern Hemisphere in Europe, Asia, and North America in the mid-latitudes, typically between 25 and 70 degrees $\mathrm{N}$ latitude (Schmitt et al. 2009), and is also part of the northern boreal forest (Faber-Langendoen et al. 2016). In temperate coniferous forests, evergreen conifers predominate, but there can be a mix of deciduous trees. The coniferous forest of the Northern Hemisphere is the main source of roundwood in the world and is therefore of significant commercial importance (McDermott et al. 2010).

In Europe, coniferous forest land cover can range from more than $80 \%$ of the total forest cover in Sweden to less than $10 \%$ of the total forest cover in Serbia (McCarthy et al. 2011). Generally, in Poland, coniferous forests constitute $68.5 \%$ of all forest land cover and, of this, $58.2 \%$ are pine forests (GUS 2017). Polish forests are composed of native tree species with mixed and structured stands consisting of several age and size cohorts. These forests are managed for multiple ecosystem services (e.g. wood and non-wood products, climate regulation, soil protection, water regulation and 
supply, recreation, biodiversity conservation, etc.), and at the same time, they address societal demands.

Most bats living in temperate zone are associated with forests. For example, 25 of the 45 bat species known in North America use forests at some point during their life cycles (Brigham 2007). In Europe, 30 out of 41 species are considered in some way connected to forests (Dietz et al. 2009). Forests provide both foraging and roosting resources for bats, and bats provide significant ecosystem services to the forests, including control of phytophagous insects (Böhm et al. 2011). Thus, bat conservation in forests is not only crucial for maintaining biodiversity but also for sustainable forest management.

Many studies show that bat activity is lower in coniferous forests compared to deciduous or mixed forests (Kalcounis et al. 1999; Russ and Montgomery 2002; Russo and Jones 2003; Tibbels and Kurta 2003). However, in Finland, coniferous forests had the highest bat activity (Wermundsen and Siivonen 2008). High foraging rates in coniferous forests have been observed for some Myotis species possibly as a result of lower tree density (Lacki et al. 2009) or greater availability of roosts (Patriquin and Barclay 2003). However, there is lower availability of roosts in coniferous forests than in deciduous and mixed forests (Ciechanowski 2005; Humes et al. 1999; Menzel et al. 2001; Perry et al. 2008).

The use of managed pine forests by bats has been studied in North America in forests dominated by Pinus taeda (Bender et al. 2015; Elmore et al. 2005; Hein et al. 2009; Loeb and Waldrop 2008; Miller 2003; Morris et al. 2010; Vindigni et al. 2009), P. ponderosa (Lacki et al. 2007), $P$. resinosa (Tibbels and Kurta 2003), and P. echinata (Loeb and Waldrop 2008); in France by $P$. pinaster (Charbonnier et al. 2014); and Chile by P. radiata (Rodriguez-San Pedro and Simonetti 2015). Managed pine forests are usually harvested with the use of clear-cuts. In many European countries, there are restrictions on the maximum size of clear-cuts. For example, they cannot exceed six hectares in Poland, ten hectares in Latvia, and 20 hectares in Sweden (McDermott et al. 2010). This harvesting system creates a mosaic of pine stands of various ages which can also be considered as a mosaic of pine stands of various densities. Clear-cuts that result from timber harvesting change the vegetation structure for bats (Brooks 2009; Hogberg et al. 2002; Kusch et al. 2004; Menzel et al. 2005; Owen et al. 2004). Although some studies have shown clear-cutting to have a negative impact on bat populations (Ancillotto et al. 2015; Erickson and West 2003; Miles et al. 2006), many others show that in managed forests, a mosaic of different ages, or densities, has a positive effect on bat populations (Bender et al. 2015; Ethier and Fahrig 2011; Jung et al. 2012; Loeb and O'Keefe 2006). Increases in bat activity have been recorded in newly harvested forests (Dodd et al. 2012; Erickson and West 2003; Titchenell et al. 2011). One mechanism to explain the increased activity is that clear-cutting creates edges, along which bats forage (Hogberg et al. 2002; Mills et al. 2013; Morris et al. 2010; Owen et al. 2004; Tibbels and Kurta 2003). Edges created in a managed pine forest mosaic are used as commuting and foraging corridors for bats (Kalcounis-Rüppell et al. 2013).

Specific silvicultural approaches in managed pine forests can improve foraging conditions for some bat species (Humes et al. 1999; Loeb and Waldrop 2008; Yates and Muzika 2006). Many studies have shown a positive effect of thinning on the general foraging activity of bats, due to a reduction in tree density and, as a consequence, reduction in clutter (Bender et al. 2015; Elmore et al. 2005; Erickson and West 2003; Loeb and Waldrop 2008; Patriquin and Barclay 2003; Tibbels and Kurta 2003). While thinning may enhance bat activity, unmanaged stands provide critical roosting resources for bats due to the presence of large, mature trees that are not felled (Kalcounis-Rüppell et al. 2005; Miles et al. 2006; Morris et al. 2010).

Given the importance of both bats and forests in Poland, and the general lack of studies on the relationships between bats and pine forest management in central Europe, the aim of our study was to compare bat activity and species diversity among four age classes (clear-cut, young, middle-aged, and mature), of managed Scots pine (Pinus sylvestris) stands in Poland. We predicted that: (1) activity of bats will be higher in clear-cuts and young stands than in middle-aged and mature stands, because in lowland Polish landscapes open- and edge-habitat foragers dominate bat assemblages (Ciechanowski 2015), (2) open-habitat adapted bat species will be more active in clear-cut and young stands due to reduced vegetation clutter, and (3) closed-habitat adapted species will be more active in mature stands, as they are adapted to flight with high vegetation clutter.

\section{Materials and methods}

\section{Study area}

This study took place in western Poland, during the summers of 2013 and 2014, in three major managed Scots pine (Pinus sylvestris) contiguous forests complexes: Drawska Forest (DF; $\left.53^{\circ} 7^{\prime}-53^{\circ} 23^{\prime} \mathrm{N}, 15^{\circ} 35^{\prime}-16^{\circ} 6^{\prime} \mathrm{E}\right)$, Notecka Forest (NF; $52^{\circ} 41^{\prime}-52^{\circ} 50^{\prime} \mathrm{N}, 15^{\circ} 55^{\prime}-16^{\circ} 27^{\prime} \mathrm{E}$ ), and Bory Dolnośląskie Forest (BD; $51^{\circ} 22^{\prime}-51^{\circ} 33^{\prime} \mathrm{N}, 15^{\circ} 35^{\prime}-16^{\circ} 2^{\prime} \mathrm{E}$ ); Fig. 1. Drawska Forest $\left(1100 \mathrm{~km}^{2}\right)$ is located on a flat plain built of fluvioglacial sands along the Drawa River at altitude 30-130 m a.s.l.; the area has numerous kettle lakes, with the surface area of the largest lake being $3.9 \mathrm{~km}^{2}$. Notecka Forest $\left(1352 \mathrm{~km}^{2}\right)$ is located on relatively flat terraces of glacial-riverine origin, covered by sandy dunes up to $90 \mathrm{~m}$ a.s.l. In Notecka forest, there are two groups of ribbon lakes with 
Fig. 1 Distribution of sample stands in (1) Drawska Forest (DF), (2) Notecka Forest (NF), (3) Bory Dolnośląskie Forest (BD) and age of the studied stands
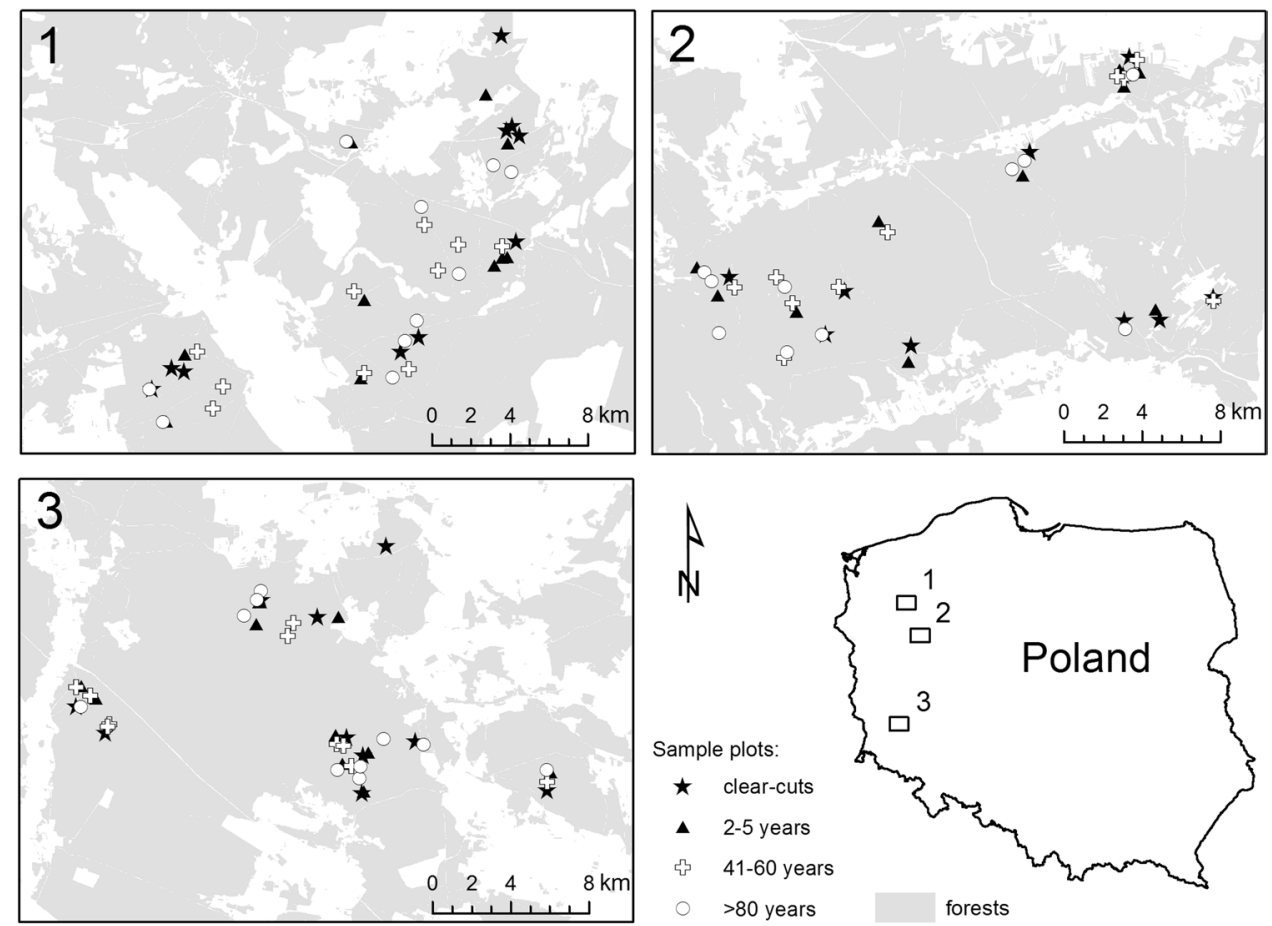

the largest having a surface area of $1.2 \mathrm{~km}^{2}$, a vast peat bog, and a chain of small, artificial reservoirs on the Miakka River which is the only river in the region. Bory Dolnośląskie Forest $\left(1650 \mathrm{~km}^{2}\right.$ ) includes a complex of moraines (up to $200 \mathrm{~m}$ a.s.l.) and alluvial fans with dunes and river valleys. There are no lakes in the Bory Dolnośląskie Forest, but there are some peat bogs and the forest is crossed by some rivers. Mean annual temperature in all three forests falls in the range of 7.5-8.5 ${ }^{\circ} \mathrm{C}$; mean temperature in January is between $-6.0^{\circ} \mathrm{C}$ and $-5.5^{\circ} \mathrm{C}$ and in July is between 15 and $16^{\circ} \mathrm{C}$. Annual precipitation in all three forests ranges between 500 and $650 \mathrm{~mm}$. The coldest forest is Drawska Forest, and the warmest forest is Bory Dolnośląskie Forest (Kożuchowski 2011).

The three forest complexes are operational forests managed according to sustainable management practices by the State Forests National Forest Holding. The forests are embedded in forested areas, composed of native tree species where Scots pine is dominant. Within each of the three forest complexes, different aged Scots pine stands were used for our study: (1) clear-cut stands, (2) young stands ranging from 2 to 5 years (average 3.4 years), (3) mid-aged stands ranging from 41 to 60 years (average 52.9 years), and (4) mature stands ranging from 81 to 100 years (average 89.7 years); Fig. 1. Sampled stands were generally single pine species, even-aged stands, without management of the understory. Young stands were $80-90 \%$ pine intermixed with other tree species, usually silver birch (Betula pendula) along edges. Best management practices for renewing clear-cuts in Poland stem from principles of sustainable forest management and include avoiding the planting of single-species coniferous stands and supporting natural regeneration (Kruk and Kornatowska 2014).

In each of the three complexes, ten experimental stands of each age class were selected for the study. Thus, each complex had 40 stands for a total of 120 sample stands (Table 1; Fig. 1). All plots were placed within a pine forest matrix to avoid landscape elements known to influence bat activity such as wide roads, buildings, rivers, and lakes
Table 1 Characteristics of sampled Scots pine stands

\begin{tabular}{lccclll}
\hline Stand age & $N$ & $\begin{array}{l}\text { Mean }( \pm \mathrm{SD}) \\
\text { area (ha) }\end{array}$ & $\begin{array}{l}\text { Mean }( \pm \mathrm{SD}) \\
\text { age (years) }\end{array}$ & $\begin{array}{l}\text { Mean }( \pm \mathrm{SD}) \\
\mathrm{DBH}(\mathrm{cm})\end{array}$ & $\begin{array}{l}\text { Mean }( \pm \mathrm{SD}) \\
\text { height }(\mathrm{m})\end{array}$ & $\begin{array}{l}\text { Mean }( \pm \mathrm{SD}) \\
\text { volume }\left(\mathrm{m}^{3}\right. \\
\left.\text { ha }^{-1}\right)\end{array}$ \\
\hline Clear-cut & 30 & $3.1 \pm 0.9$ & - & - & - & - \\
Young & 30 & $3.2 \pm 0.6$ & $3.4 \pm 1.2$ & - & $<1$ & - \\
Middle-aged & 30 & $7.4 \pm 5.1$ & $52.9 \pm 6.3$ & $18.7 \pm 3.8$ & $17.4 \pm 3.0$ & $248 \pm 59$ \\
Mature & 30 & $10.9 \pm 6.8$ & $89.7 \pm 6.2$ & $28.5 \pm 4.5$ & $21.7 \pm 2.4$ & $306 \pm 49$ \\
\hline
\end{tabular}


(Ciechanowski 2015; Mehr et al. 2011). All sample stands had a minimum size of two hectares.

Based on known geographic ranges and distribution patterns, we expected approximately 18 bat species belonging to three foraging guilds: open-habitat foragers (Nyctalus noctula, N. leisleri, Vespertilio murinus, Eptesicus serotinus, E. nilssonii, Pipistrellus nathusii); edge-habitat foragers (Pipistrellus pipistrellus, P. pygmaeus, Barbastella barbastellus, Myotis daubentonii, M. dasycneme, M. mystacinus, $M$. brandtii, M. myotis); and closed-habitat foragers ( $M$. nattereri, M. bechsteinii, Plecotus auritus, P. austriacus). Among them, M. bechsteinii, M. brandtii, M. mystacinus, and $P$. austriacus are more likely to occur in the southernmost forest complex (Bory Dolnośląskie), because of their distribution in Poland (Sachanowicz et al. 2006).

\section{Bat sampling}

Bats were sampled acoustically with a broadband Pettersson D1000X bat detector (Pettersson Elektronik AB, Sweden). In any given stand, we sampled bats continuously for three hours, starting 15 min after sunset, by walking non-stop, in a random way, through the stand. We were careful to spend the same amount of time in each stand and to keep our walking to the interior of the stand by avoiding edges (we were at least $20 \mathrm{~m}$ from any edge while walking). Each stand was sampled by the same person during each night. Bats were sampled in 2013, from July 1 to August 13, and in 2014 from June 24 to August 15. Each year, we examined five different stands per type in each forest complex. We did not sample if it was raining. Every stand was sampled only once. Weather data (air temperature $\left[{ }^{\circ} \mathrm{C}\right]$, relative humidity [\%], and wind speed $[\mathrm{m} / \mathrm{s}]$ ) were obtained from weather stations managed by Institute of Meteorology and Water Management in Piła (for Drawska Forest), Poznań (Notecka Forest) and Legnica (Bory Dolnośląskie Forest).

\section{Bat echolocation analyses}

Recorded echolocation passes were analysed using Pettersson BatSound software v. 4.0 (Pettersson Elektronik AB, Sweden). We used bat passes as sampling unit to describe bat activity within our sampling sites. A bat pass consisted of a sequence of at least two calls (Rachwald 1992; Thomas 1988), separated from the next call by an interval ten times longer than the interval between the last two calls of the sequence (Ciechanowski 2015). However, bat passes were not used to quantify bat activity for the noctule bat ( $\mathrm{Nyc}$ talus noctula) because recordings of the noctule bat reveal constant activity, likely produced by several individuals and resulting in a continuous recording of overlapping passes for long periods, partially because of the exceptionally long range of the species' detection (sometimes 100-150 m)
(Barataud 2015). Treating such a recording of overlapping passes as a single 'pass' would result in underestimation of species' activity, especially in exceptionally high foraging sites. To overcome this, we measured a series of 100 'single' call sequences for that species (associated with unidirectional, commuting flights), calculated a mean value, and used that time interval as an activity unit (a proxy for bat pass). We also noted, for all species, whether each sequence contained a feeding buzz.

We classified bat calls manually, comparing the visible features or characters measured on spectrograms (shape, peak frequency, duration, intervals) with those available from the literature (Ahlén 1990; Barataud 2015; Skiba 2003; Vaughan et al. 1997). We made this decision because of concerns with automated species recognition (Rydell et al. 2017) and because identification of every call to the species level was not necessary to test our hypotheses. There are two groups of central European bat species that are especially difficult to distinguish based on their echolocation calls mostly due to strong overlap in their call parameters: (1) Nyctalus/Eptesicus/Vespertilio (NEV) and (2) Myotis spp. (MSP). However, within these groups, some species can be distinguished from other species in the group if they emit particular types of calls. We were able to identify Nyctalus noctula to species level, if we recorded quasi-constant frequency (QCF) calls with frequency at maximum amplitude below $22 \mathrm{kHz}$ (peak frequency, PF) (Ahlén 1990; Barataud 2015; Skiba 2003). Within the NEV group, we also excluded possibility of recording Nyctalus lasiopterus, as it is rare in Poland, having only been recorded twice, once in owl pellet remains, and once in a questionable mist-net capture (Sachanowicz et al. 2006). The remaining species within the NEV group were rarely identified to species with the following exceptions. Sequences with an alternate pattern of longer QCF and shorter FM-qcf calls with an explosive start visible on the oscillogram and PF $22-25 \mathrm{kHz}$ were identified as $N$. leisleri, while those QCF calls with an explosive start and PF 24-26 kHz but lacking the alternating QCF and FM-qcf pattern were identified as Vespertilio murinus. FM-qcf calls with irregular rhythm, with a progressive start visible on the oscillogram and $\mathrm{PF} 27-29 \mathrm{kHz}$, were identified as Eptesicus serotinus, while those with an explosive start and $\mathrm{PF}>30 \mathrm{kHz}$ were identified as E. nilssonii (Ahlén 1990; Barataud 2015; Skiba 2003). Calls were classified as FM-qcf when the frequency modulated part of the call predominated the call, while the quasi-constant frequency part formed only the end of the call. Any call sequence belonging to Nyctalus, Eptesicus, or Vespertilio that failed to reveal the whole combination of diagnostic features typical for species was assigned to the NEV group only. Most calls representing Myotis (M. daubentonii, M. dasycneme, M. mystacinus, M. brandtii, M. nattereri, M. bechsteinii) were identified only to the genus level (Ahlén 1990; Ahlén and Baagøe 1999). 
We were able to identify $M$. nattereri when foraging in high clutter, due to its extreme broadband calls that start well above $100 \mathrm{kHz}$ (often up to $135 \mathrm{kHz}$ ) and end below $20 \mathrm{kHz}$ (Siemers and Schnitzler 2004), a feature not found in any other Myotis species. We were also able to distinguish the larger M. myotis by a low PF $(\sim 30 \mathrm{kHz})$ and repetition rate (Ahlén 1990; Barataud 2015; Skiba 2003). Lastly, we include a sonogroup PLE for all species from the genus Plecotus (P. auritus, P. austriacus) and PSP for all species in the genus Pipistrellus ( $P$. pipistrellus, $P$. pygmaeus, $P$. nathusii, P. kuhlii).

Although most of the echolocation passes were assigned to a bat species (79.5\%), some were classified only to genus or groups, and some remained identified (UNID). All recorded bat passes (except for unidentified species) were assigned to one of the three foraging guilds: open-habitat foragers, edge-habitat foragers, and closed-habitat foragers according to Müller et al. (2012). Echolocation call data were converted into response variables, bat activity was calculated as number of bat passes per night $(3 \mathrm{~h})$ including those with feeding buzzes.

\section{Statistical analyses}

Our response variables were counts of bat passes collected during the study and categorized into those from three foraging guilds: closed-, edge-, and open-habitat foragers; those from the MSP group; those from all bats that included feeding buzzes; and those from all bats combined. Stand age, region and year (categorical) and temperature and wind (continuous) were included in analysis as predictors. Humidity and day of year were excluded from the analysis to avoid collinearity, as they were correlated with ambient temperature (Pearson's correlation, $r=-0.50$, $p<0.001$ and $r=0.27, p=0.003$, respectively). Our distributions of bat passes were right-skewed because of zeros in the dataset. We used generalized linear models (GLMs) with discrete distribution as recommended by Warton et al. (2016). For each response variable, GLMs were computed with Poisson, negative binomial (both with log link function) and zero-inflated Poisson (logit link function) distributions because log transformation is not recommended for these types of data sets (O'Hara and Kotze 2010). We then compared AIC values among the models. In each case, the GLM with negative binomial distribution had the lowest AIC values and were subjected to following analyses. Analyses of deviance were conducted with error estimate based on the Pearson residuals and F-test statistic. If categorical predictors were significant (criterion $p<0.05$ ), estimated marginal means (EMMs) were computed and Tukey post hoc test conducted. Statistical analyses were done in $\mathrm{R}$ 3.4.4 (R Core Team 2018) using function glm(MASS) for GLM with Poisson distribution, glm.nb(MASS) for GLM with negative binomial distribution (Venables and Ripley 2002), and zeroinfl(pscl) for GLM with zero-inflated Poisson distribution (Zeileis et al. 2008). Analyses of deviance were computed with function Anova(car) (Fox and Weisberg 2011). In order to test for differences between categories, function emmeans(emmeans) was used for computation of EMMs and function cld(emmeans) for Tukey post hoc tests (Lenth 2018).

\section{Results}

Across all 120 stands, a total of 19,180 bat passes were recorded. Overall, $79.5 \%$ of bat passes were identified to species, $18.0 \%$ identified to sonotype group, and $2.5 \%$ remained unidentified. In total, 11 species of bats and four sonotype groups were recorded. The dominant species was the noctule bat (Nyctalus noctula; $71.5 \%$ ), followed by the common pipistrelle (Pipistrellus pipistrellus; $4.6 \%$ ) and serotine bat (Eptesicus serotinus; $1.7 \%$ ). The remaining eight species that made up $1.7 \%$ of the total passes were the Nathusius' pipistrelle (Pipistrellus nathusii), greater mouse-eared bat (Myotis myotis), soprano pipistrelle (Pipistrellus pygmaeus), Natterer's bat (Myotis nattereri), western barbastelle (Barbastella barbastellus), lesser noctule (Nyctalus leisleri), northern bat (Eptesicus nilssonii), and parti-coloured bat (Vespertilio murinus) (Table 2). Of the four sonotype groups, the largest was NEV (Nyctalus spp./Eptesicus spp./V. murinus), followed by MSP (Myotis spp.), PSP (Pipistrellus spp.), and PLE (long-eared bats Plecotus spp.; Table 2). Feeding buzzes were in $8.4 \%$ of total passes.

Open-habitat foragers were represented by six species of bats and the NEV group, edge-habitat foragers were represented by four species, and closed-habitat foragers were represented by only one species and the PLE group (Table 2). Two sonotype groups (MSP and PSP) could not be clearly assigned to single foraging guild (Table 2). MSP included edge-habitat foragers as well as closed-habitat foragers, while the PSP included both open-habitat foragers and edgehabitat foragers (Table 2).

Across all stand ages, most bat passes were recorded for open-habitat foragers $(89.1 \%)$, followed by edge-habitat foragers $(5.0 \%)$, and closed-habitat foragers $(0.4 \%)$. The remainder of passes $(5.5 \%)$ were not assigned to any of the foraging guilds (Table 2). GLMs indicated a positive correlation between bat activity and temperature (Table 3 ). For all bats, passes increased by $6.8 \%$ per $1{ }^{\circ} \mathrm{C}$ increase (Table 3) with specific increases in passes for closed-habitat foragers being $2 \%$, for edge-habitat foragers being $7.5 \%$, and for open-habitat foragers being $6.9 \%$. Feeding buzzes also increased by $10.6 \%$ per $1{ }^{\circ} \mathrm{C}$ (Table 3 ).

There were a high number of open-habitat forager passes for all bats, and the number of passes for all bats was 2-3 
Fig. 2 All observations (dots), quartiles (black boxes), mean (middle of grey whiskers) and standard error from the mean (outermost dashes of grey whiskers) number of bats passes per night $(3 \mathrm{~h})$. Dots are semi-transparent for indication of the density of data points. Statistics are arranged in columns (stand age, region and year), and in rows for three foraging guilds (closed-, edge- and open-habitat foragers), MSP group, feeding buzzes of all bats and the summary of passes for all bats. The ordering of the figure follows the generalized linear models (dependent variables in rows) and their fixed, noncontinuous factors (in columns) for which F-tests were conducted (Table 4) and estimated marginal means (EMMs) were computed. For each figure denoting "stand age" and "region", different letter(s) above the grey whiskers indicate statistically significant $(\alpha=0.05)$ difference between EMM computed for factor levels, as a result of post hoc Tukey test (adjusted only for significant factors with more than two levels). See details in Table 4. We did not use letters to denote significant differences for "year" because there are only two groups (see Table 4 for significant year differences). Note: scale of ordinate axis is different for each row; results for "stand age" are over the levels of "region" and "year"; for "region" over the levels of "stand age" and "year"; and for "year" over the levels of "stand age" and "region". Hence, each chart presents 120 data points. Detailed results of analyses of deviance are reported in Table 4 . The names of the regions are shown in Fig. 1
Table 2 Species of bats recorded and identified from all stands

\begin{tabular}{llccl}
\hline No & Bat species or sonotype group & $\begin{array}{c}\text { Total number } \\
\text { of bat passes }\end{array}$ & $\begin{array}{l}\text { Mean }( \pm \text { SE) } \\
\text { passes per night } \\
(3 \mathrm{~h})\end{array}$ & Foraging guild \\
\hline 1 & Nyctalus noctula -common noctule & 13,719 & $114.33 \pm 12.31$ & $\mathrm{O}$ \\
2 & NEV (Nyctalus spp./Eptesicus spp./V. murinus) & 2817 & $23.48 \pm 3.48$ & $\mathrm{O}$ \\
3 & Pipistrellus pipistrellus-common pipistrelle & 874 & $7.28 \pm 1.22$ & $\mathrm{E}$ \\
4 & MSP (Myotis spp.) & 460 & $3.83 \pm 0.39$ & $\mathrm{E} / \mathrm{C}$ \\
5 & Eptesicus serotinus - serotine bat & 334 & $2.78 \pm 0.52$ & $\mathrm{O}$ \\
6 & Pipistrellus nathusii-Nathusius' pipistrelle & 208 & $1.73 \pm 0.32$ & $\mathrm{O}$ \\
7 & PSP (Pipistrellus spp.) & 119 & $0.98 \pm 0.21$ & $\mathrm{O} / \mathrm{E}$ \\
8 & Myotis myotis-greater mouse-eared bat & 51 & $0.43 \pm 0.11$ & $\mathrm{E}$ \\
9 & PLE (Plecotus spp.) & 50 & $0.42 \pm 0.10$ & $\mathrm{C}$ \\
10 & Pipistrellus pygmaeus-soprano pipistrelle & 34 & $0.28 \pm 0.06$ & $\mathrm{E}$ \\
11 & Myotis nattereri-Natterer's bat & 32 & $0.27 \pm 0.07$ & $\mathrm{C}$ \\
12 & Barbastella barbastellus-western barbastelle & 3 & $0.03 \pm 0.01$ & $\mathrm{E}$ \\
13 & Nyctalus leisleri-lesser noctule & 3 & $0.03 \pm 0.02$ & $\mathrm{O}$ \\
14 & Eptesicus nilssonii-northern bat & 1 & $0.01 \pm 0.01$ & $\mathrm{O}$ \\
15 & Vespertilio murinus-parti-coloured bat & 1 & $0.01 \pm 0.01$ & $\mathrm{O}$ \\
16 & UNID—unidentified species & 476 & - & - \\
\hline
\end{tabular}

Foraging guilds: $\mathrm{O}$-open-habitat foragers, $\mathrm{E}$ - edge-habitat foragers, $\mathrm{C}$-closed-habitat foragers (Müller et al. 2012)

In some cases, passes could only be assigned to sonotype group or were unidentifiable (UNID). For each species and sonotype group, we note the total number of bat passes from among the total recorded $(19,180)$ and the foraging guild to which they belong from Müller et al. (2012)
Table 3 Back-transformed (by exponential function) estimates $(\beta)$ and standard error $( \pm \mathrm{SE})$ of estimates (in brackets) of continuous predictors (intercept, temperature and wind) from generalized linear models on values of bat passes and feeding buzzes for all bat species together and passes of each foraging guild separately

\begin{tabular}{lllr}
\hline & Intercept & Temperature & Wind \\
\hline All bats & $150.2(1.490)^{* * *}$ & $1.068(1.020)^{* *}$ & $0.934(1.065)^{\text {n.s. }}$ \\
Closed-habitat foragers & $0.191(3.031)^{\text {n.s. }}$ & $1.020(1.055)^{\text {n.s. }}$ & $0.860(1.177)^{\text {n.s. }}$ \\
Edge-habitat foragers & $8.855(1.709)^{* * *}$ & $1.075(1.028)^{*}$ & $0.907(1.093)^{\text {n.s. }}$ \\
Open-habitat foragers & $140.5(1.554)^{* * *}$ & $1.069(1.022)^{* *}$ & $0.948(1.073)^{\text {n.s. }}$ \\
MSP & $1.014(1.701)^{\text {n.s. }}$ & $1.084(1.028)^{* *}$ & $0.851(1.085)^{\text {n.s. }}$ \\
Feeding buzzes & $14.59(1.799)^{* * *}$ & $1.106(1.032)^{* *}$ & $0.915(1.102)^{\text {n.s. }}$ \\
\hline
\end{tabular}

Significance level of each estimate (n.s. $\left.p>0.05,{ }^{*} p<0.05, * * p<0.01, * * * p<0.001\right)$ is based on calculated Walds $z$-score $=\ln (\beta) / \ln (\operatorname{SE}(\beta))$ 


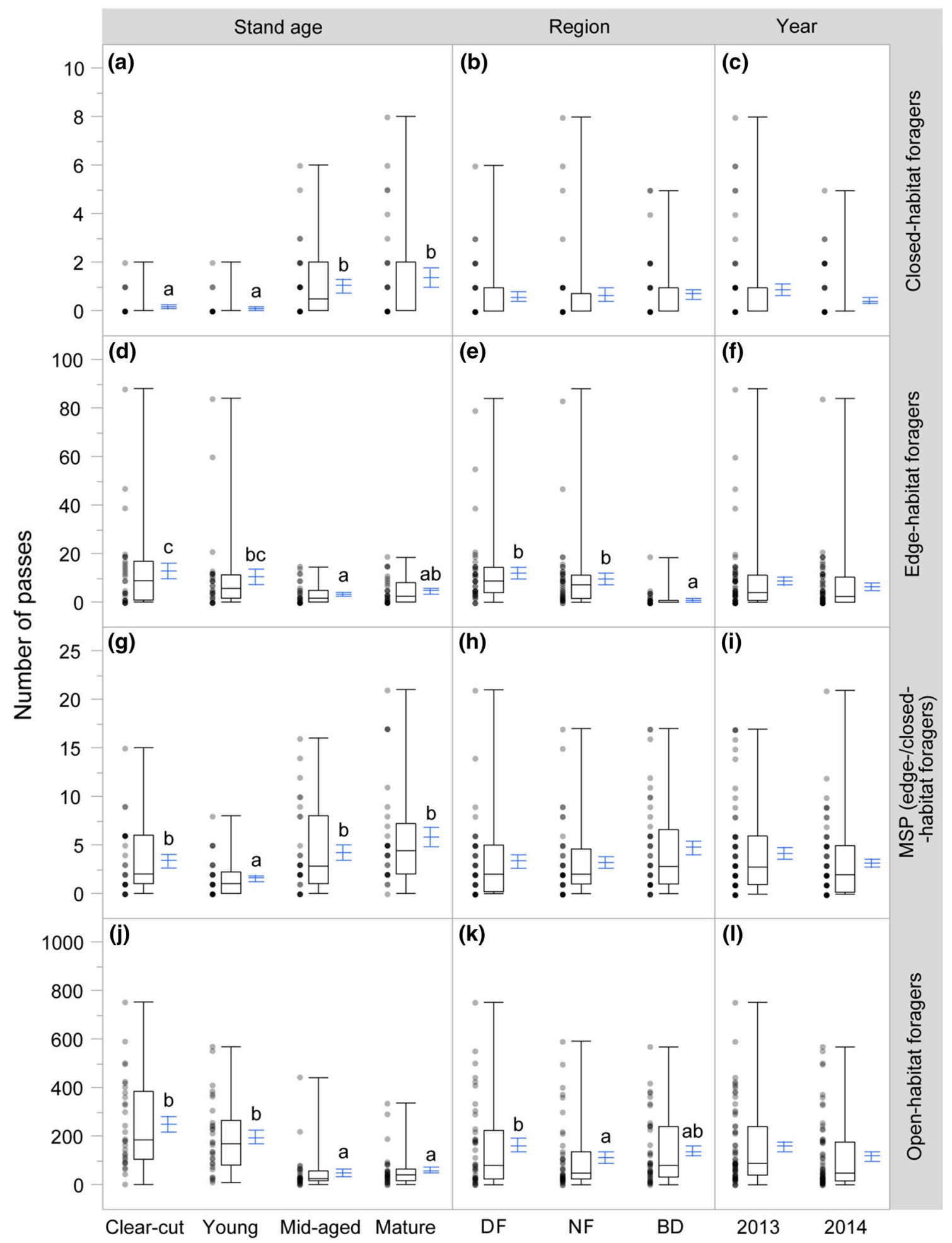




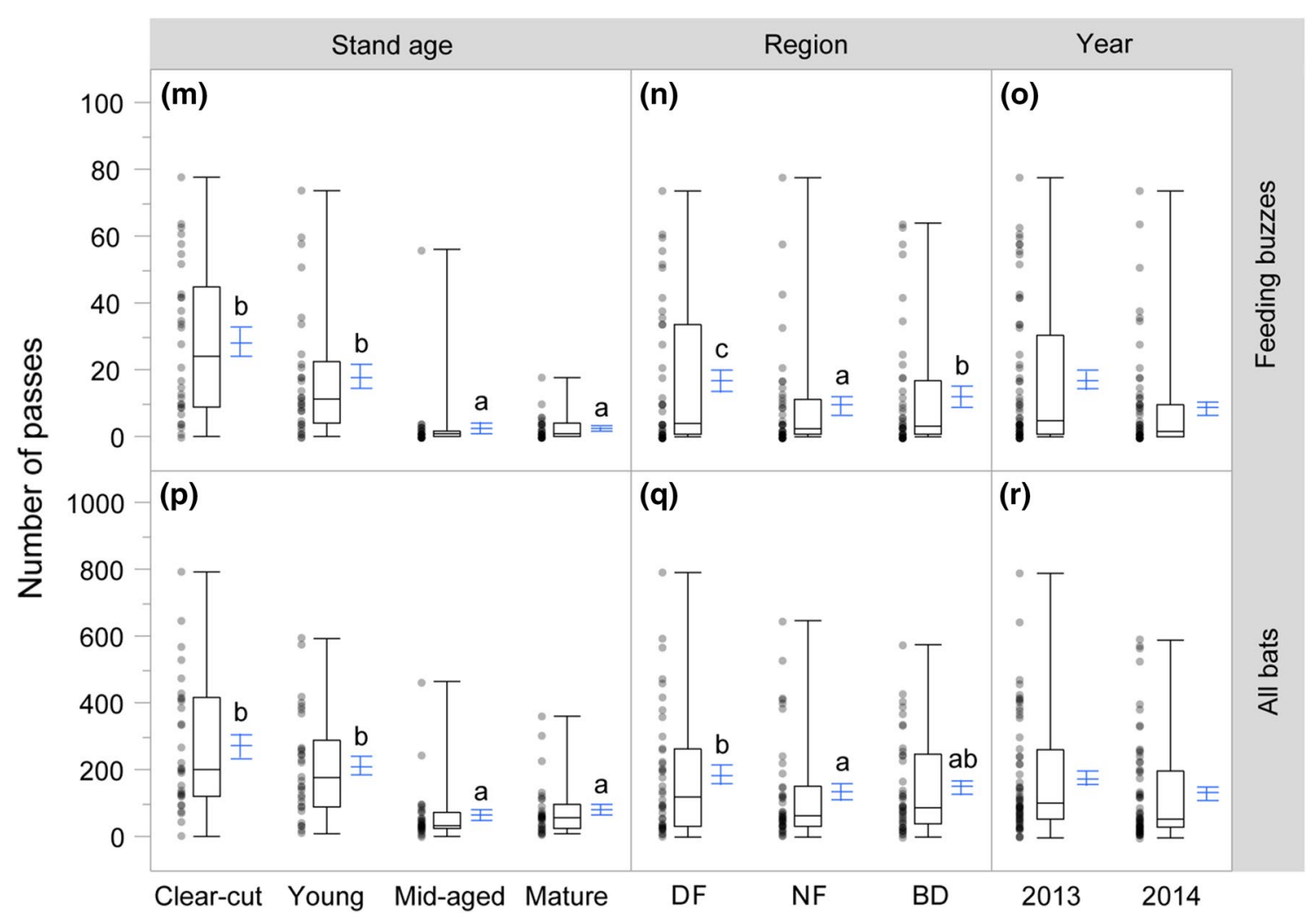

Fig. 2 (continued)

times higher in open clear-cut and young stands when compared to middle-aged and mature stands (Fig. 2p). Across several bat response variables, bat activity was similar in clear-cuts and young stand and similar in mid-aged and mature stands (see, for example, Fig. 2a, j, m, p). In clear-cut and young stands, we observed a higher number of passes for edge-habitat foragers (Fig. 2d), open-habitat foragers (Fig. 2j), all bats (Fig. 2p), and feeding buzzes (Fig. 2m) when compared to mid-aged and mature stands. The activity of closed-habitat foragers was associated with mid-aged and mature stands (Fig. 2a), but the number of passes was relatively low (maximum of eight). The MSP group had the most similar activity among stands (Fig. $2 \mathrm{~g}$ ).

The number of bat passes was low in NF for open-habitat foragers (Fig. 2k) and all bats (Fig. 2q), and low in BD for edge-habitat foragers (Fig. 2e), when compared to the other forest regions. The number of passes with feeding buzzes differed across regions and was highest in DF (Table 4, Fig. 2). Closed-habitat foragers (Fig. 2b) and MSP (Fig. 2h) did not differ in bat activity among forest regions. The number of feeding buzzes was higher in 2013 (Fig. 20).

The total number of bat species and the species richness did not differ among stand ages (Table 5).

\section{Discussion}

Our study revealed that stand age is a factor that shapes commuting and feeding activity of bats in managed pine forests in Poland. As in other regions (Brooks and Ford 2005), bats responded to two stand age types in forest regions in Poland. We found that clear-cuts and young stands had 2-3 times higher bat activity compared middle-aged and mature stands, consistent with the observations of others (Kusch et al. 2004; Loeb and O'Keefe 2006; Menzel et al. 2002, 2005). However, we also recorded the majority of all activity in clear-cuts and young stands so our results need to be considered in this context. Tibbels and Kurta (2003) found that bat activity in open areas of pine forests (Pinus resinosa) could be up to 20 times higher than inside the stand. Prey availability may be higher in clear-cuts and young stands (Charbonnier et al. 2014; Loeb and O'Keefe 2006; Morris et al. 2010). However, while some studies have shown a greater availability of insects in the open habitats (Lunde and Harestad 1986; Tibbels and Kurta 2003), others have shown higher insect availability in the interior of stands (Grindal and Brigham 1999; Kalcounis and Brigham 1995; Menzel et al. 2005; Müller et al. 2012) or at the edges of stands (Morris et al. 2010). Other stand parameters may be more important than the availability of insects (Dodd et al. 2012; 
Table 4 Outcome of analyses of deviance after computation of generalized linear models of bat passes and feeding buzzes for all bat species together and passes of each foraging guild separately

\begin{tabular}{|c|c|c|c|c|c|c|}
\hline Variable & Source & SS & $d . f$. & MS & $F$ & $p$ \\
\hline \multirow[t]{6}{*}{ Closed-habitat foragers } & Temperature & 0.13 & 1 & 0.13 & 0.12 & 0.73 \\
\hline & Wind & 0.82 & 1 & 0.82 & 0.73 & 0.39 \\
\hline & Region & 0.02 & 2 & 0.01 & 0.01 & 0.99 \\
\hline & Year & 1.44 & 1 & 1.44 & 1.29 & 0.26 \\
\hline & Stand age & 28.44 & 3 & 9.48 & 8.50 & $<0.001$ \\
\hline & Error & 123.80 & 111 & 1.12 & & \\
\hline \multirow[t]{6}{*}{ Edge-habitat foragers } & Temperature & 5.52 & 1 & 5.52 & 4.00 & 0.05 \\
\hline & Wind & 1.15 & 1 & 1.15 & 0.83 & 0.36 \\
\hline & Region & 88.73 & 2 & 44.37 & 32.06 & $<0.001$ \\
\hline & Year & 3.29 & 1 & 3.29 & 2.38 & 0.13 \\
\hline & Stand age & 30.09 & 3 & 10.03 & 7.25 & $<0.001$ \\
\hline & Error & 153.65 & 111 & 1.39 & & \\
\hline \multirow[t]{6}{*}{ Open-habitat foragers } & Temperature & 6.93 & 1 & 6.93 & 5.47 & 0.02 \\
\hline & Wind & 0.59 & 1 & 0.59 & 0.47 & 0.50 \\
\hline & Region & 11.60 & 2 & 5.80 & 4.58 & 0.01 \\
\hline & Year & 5.34 & 1 & 5.34 & 4.21 & 0.04 \\
\hline & Stand age & 86.04 & 3 & 28.68 & 22.63 & $<0.001$ \\
\hline & Error & 140.67 & 111 & 1.27 & & \\
\hline \multirow[t]{6}{*}{ MSP } & Temperature & 7.77 & 1 & 7.77 & 6.97 & 0.01 \\
\hline & Wind & 4.07 & 1 & 4.07 & 3.65 & 0.06 \\
\hline & Region & 5.29 & 2 & 2.65 & 2.37 & 0.10 \\
\hline & Year & 0.04 & 1 & 0.04 & 0.04 & 0.85 \\
\hline & Stand age & 27.18 & 3 & 9.06 & 8.13 & $<0.001$ \\
\hline & Error & 123.68 & 111 & 1.11 & & \\
\hline \multirow[t]{6}{*}{ Feeding buzzes } & Temperature & 9.14 & 1 & 9.14 & 6.63 & 0.01 \\
\hline & Wind & 0.80 & 1 & 0.80 & 0.58 & 0.45 \\
\hline & Region & 23.47 & 2 & 11.74 & 8.51 & $<0.001$ \\
\hline & Year & 18.27 & 1 & 18.27 & 13.25 & $<0.001$ \\
\hline & Stand age & 120.93 & 3 & 40.31 & 29.24 & $<0.001$ \\
\hline & Error & 150.01 & 111 & 1.35 & & \\
\hline \multirow[t]{6}{*}{ All bats } & Temperature & 8.44 & 1 & 8.44 & 7.14 & $<0.01$ \\
\hline & Wind & 1.22 & 1 & 0.19 & 1.03 & 0.31 \\
\hline & Region & 11.11 & 2 & 5.56 & 4.71 & 0.01 \\
\hline & Year & 4.99 & 1 & 4.99 & 4.22 & 0.04 \\
\hline & Stand age & 82.35 & 3 & 27.45 & 23.25 & $<0.001$ \\
\hline & Error & 131.04 & 111 & 1.18 & & \\
\hline
\end{tabular}

SS — adjusted sum of squares, MS — calculated square means, $d . f$. degrees of freedom

\begin{tabular}{llllll}
\hline Stand age & $\begin{array}{l}\text { Total number } \\
\text { of bat passes }\end{array}$ & $\begin{array}{l}\text { Percentage of } \\
\text { feeding buzzes } \\
(\%)\end{array}$ & $\begin{array}{l}\text { Mean }( \pm \mathrm{SE}) \\
\text { passes per night } \\
(3 \mathrm{~h})\end{array}$ & $\begin{array}{l}\text { Total number } \\
\text { of bat species }\end{array}$ & $\begin{array}{l}\text { Mean }( \pm \mathrm{SE}) \\
\text { species richness }\end{array}$ \\
\hline clear-cut & 8271 & 10.4 & $223 \pm 30$ & 8 & $3.57 \pm 0.29$ \\
young & 6469 & 8.5 & $178 \pm 26$ & 9 & $3.33 \pm 0.26$ \\
middle-aged & 1969 & 4.4 & $50 \pm 14$ & 9 & $2.63 \pm 0.26$ \\
mature & 2473 & 3.1 & $58 \pm 13$ & 8 & $3.00 \pm 0.22$ \\
\hline
\end{tabular}

Table 5 The total number of bat passes, percentage of feeding buzzes in the total number of bat passes, mean number of passes per night $(3 \mathrm{~h})$, number of bat species and mean species richness across Scots pine stand ages 
Loeb and Waldrop 2008; Menzel et al. 2005; Morris et al. 2010; Titchenell et al. 2011). For example, reduced clutter in clear-cuts and young stands may increase activity of all bat species belonging to open- and edge-habitat foraging guilds (Müller et al. 2013). The degree to which bats use cluttered habitat types is related to bat morphology, including body mass, wing shape, aspect ratio, and echolocation call characteristics (Bender et al. 2015). In general, highly manoeuvrable species with short and broad wings are better adapted to foraging in cluttered forest conditions, whereas bats with long and narrow wings often forage over the forest canopy or in forest openings (Loeb and O'Keefe 2006; Menzel et al. 2005).

Temperature also affected bat activity in our study. Temperature correlates with nightly activity of aerial-hawking bats (i.e. open- and edge-habitat foragers) (Ciechanowski et al. 2007; Maier 1992; Russ et al. 2003) probably through effects on the activity of airborne insect prey (Rydell 1989). It is worth noting that, in our study, closed-habitat foragers did not respond to temperature, either because that guild is composed of gleaners that forage on either non-volant or dormant insects (Dietz et al. 2009) or because they were recorded very low levels of activity of closed-habitat foragers and our sample sizes may have been too small to detect a temperature effect. The effect of region in edge-habitat foragers, dominated by Pipistrellus pipistrellus, is likely due to the patchy distribution of $P$. pipistrellus in Poland where it is more common in the northern lakeland zone than in central and southern lowlands (Sachanowicz et al. 2006). Other factors such as insect availability may also be important in predicting bat activity, but we did not measure insect availability and this is something to consider for future work.

We found no significant differences in bat activity between middle-aged and mature stands for all analysed groups of bats suggesting that middle-aged and mature stands support similar levels of bat activity and similar diversity. Scots pine stands aged 40-60 years (mid-age) have a higher density of trees, and therefore clutter, than mature-aged stands. However, our results suggest that clutter is not limiting closed-habitat foragers because we find similar levels of activity in both habitats. Humes et al. (1999) found that old-growth stands and thinned younger stands were similar in structure, and they did not differ significantly in amount of use by bats. In our case, mid-aged stands were more cluttered (see photographs of stand types in supplementary material) so it is unlikely that stand structure similarities between mid-aged and mature stands explain our results. Our results differ from other studies which show that bats used older stands more than younger ones (Adams et al. 2009; Crampton and Barclay 1998; Lacki et al. 2007; Menzel et al. 2005). It is important to note that activity of bats in stands of different ages is species specific. For example while Lasiurus borealis does not show an affinity to any age class (Elmore et al. 2005), Pipistrellus subflavus is more likely to be recorded in early-successional stands than in mature stands (Loeb and O'Keefe 2006). We found high levels of activity of bats in clear-cut and open stands, whereas other studies have shown higher activity in mature stands (Adams et al. 2009; Crampton and Barclay 1998; Elmore et al. 2005; Hogberg et al. 2002; Humes et al. 1999; Kalcounis et al. 1999; Lacki et al. 2007; Menzel et al. 2005; Patriquin and Barclay 2003). Although one reason to explain increased bat activity in older stands may be a greater availability of insects (Crampton and Barclay 1998), the evidence for stand age correlating with insect availability is weak (Dodd et al. 2008; Morris et al. 2010; Titchenell et al. 2011). Another reason to explain high activity in mature stands is the increased availability of roosts in older stands (Crampton and Barclay 1998; Erickson and West 2003; Loeb and O'Keefe 2006; Menzel et al. 2005). Regardless, we did not find high levels of activity in mature stands but rather found high levels of activity in clear-cut and open stands which was primarily driven by open-habitat foragers who are likely not able to navigate mature stands due to limitations on their manoeuvrability.

Only $8.4 \%$ of our recordings contained feeding buzzes which is lower than has been reported in similar studies: 9.6-22.3\% (Brooks and Ford 2005; Kalcounis et al. 1999; Menzel et al. 2002; Morris et al. 2010; Russo and Jones 2003). Like Tibbels and Kurta (2003), a greater proportion of our feeding buzzes were from clear-cut and young stands. Feeding buzzes are often of higher frequency and lower amplitude than search phase calls (Kalko and Schnitzler 1993), and thus, their detectability is disproportionally lower in more cluttered environments, due to higher sound attenuation (Patriquin and Barclay 2003). Thus, our lower proportion of feeding buzzes in middle-aged and mature stands might be an artefact of lower detectability. Alternatively, due to our low sample sizes in mid-aged and mature stands, we may not be adequately estimating feeding buzzes in these stand types, independent of detectability. Regardless, we still show that these bats were feeding in the middleaged and mature stands.

Our results demonstrate that bat species from different foraging guilds showed a clear preference in the selection of stand age while active. Open-habitat foragers were significantly more active in the clear-cut and young stands, as seen in other studies (Brooks 2009; Brooks and Ford 2005; Jung et al. 2012; Owen et al. 2004; Rachwald 1992). However, despite this preference shown by open-habitat foragers, it is important to note that in the open, open-habitat foragers like $N$. noctula tend to fly close to the forest edge (Ciechanowski 2015). Open-habitat foragers preferred larger clear-cuts in comparison with small gaps (Patriquin and Barclay 2003), due to low manoeuvrability and wing morphology which is an adaptation to fast, straight-line flight (Baagøe 1987). 
Edge-habitat foragers were similar to open-habitat foragers and had greater activity in cuts and young stands (Jung et al. 2012; Mehr et al. 2012; Schnitzler et al. 2003).

We separately analysed the MSP group that included two foraging guilds, the close-habitat foragers and edge-habitat foragers. The activity pattern of the MSP group was similar to the activity pattern of the close-habitat forager group. At least in the two northern study sites, this group might consist mainly of $M$. daubentonii, a water-surface forager (Dietz et al. 2009) common in Polish lakelands (Sachanowicz et al. 2006). Despite the clear morphological and behavioural adaptations for hunting insects above water bodies, $M$. daubentonii forage in forests as well (Ahlén 1990; Nyholm 1965) and roost in pine forests (Kasprzyk and Ruczyński 2001). Thus, we may have been recording emerging and commuting individuals (Thomas 1988). In addition, as only a small portion of $M$. nattereri calls can be safely assigned to species level (Skiba 2003), we cannot exclude its presence in the MSP bats. Other studies confirm that Myotis species prefer forest interiors (Brooks and Ford 2005; Dodd et al. 2012; Morris et al. 2010; Owen et al. 2003, 2004; Patriquin and Barclay 2003), but avoid dense stands (Mills et al. 2013; Plank et al. 2012) which is consistent with our results.

Across all stand ages, the most active guild was open-habitat foragers. This was surprising in middle-aged and mature stands which are cluttered habitats. An explanation for this result may be the large range of the microphone detector and the high probability of acoustic detection of $N$. noctula (Skiba 2003). A significant proportion of this group's calls recorded inside the stands could have come from individuals flying over the canopy (Kalcounis et al. 1999). This is, presumably, one of the reasons for unusually broad habitat niche in N. noctula (Ciechanowski 2015). Thus, it is important to keep in mind the biases of acoustic sampling (Loeb and O'Keefe 2006). In an open environment, without clutter, bat signals can be recorded from greater distances. Bats that feed inside the stand use echolocation signals with a shorter range, which may limit their detection by the detectors (Froidevaux et al. 2014; Russo and Jones 2003; Schnitzler and Kalko 2001). In stands with forest interior habitat, bat activity for these species was, presumably, recorded inside the stand, under the canopy. The canopy could be also a source of serious bias in estimation of the bat assemblage because bats stratify along the vertical forest axis (Kalcounis et al. 1999) and some individuals, belonging to species producing low-intensity calls high in the canopy cannot be recorded from the ground level (Adams et al. 2009; Menzel et al. 2005; Müller et al. 2013).

In our study, we identified 11 species of bats and four sonotype groups. Species richness was relatively high compared with other acoustic studies of bats in pine forests. For comparison, four species of bats were recorded in Chile (Rodriguez-San Pedro and Simonetti 2015), 5-9 in the USA
(Bender et al. 2015; Hein et al. 2009; Loeb and Waldrop 2008; Morris et al. 2010; Tibbels and Kurta 2003; Vindigni et al. 2009) and nine in France (Charbonnier et al. 2014). However, our sample was dominated by Nyctalus noctula (71.5\%), and this differed from the other studies whereby the dominant species represented $22-56 \%$ of the recordings (Bender et al. 2015; Hein et al. 2009; Loeb and Waldrop 2008; Morris et al. 2010; Tibbels and Kurta 2003; Vindigni et al. 2009). Similar results were obtained on intensively managed Sitka spruce plantations in the UK, where nine bat species were found, although in that case activity was dominated by two species: Pipistrellus pipistrellus and $P$. pygmaeus (Kirkpatrick et al. 2017). Although we did not find that species richness (including sonotypes) differed among stand ages, a previous study in mixed forests of Switzerland revealed that species richness was higher in gaps (i.e. open-habitat types) than in stand interiors (Froidevaux et al. 2014).

Bats may benefit from a mosaic of stand types (Bender et al. 2015; Borkin and Parsons 2014). In open areas after clear-cut harvesting, bats appear in greater abundance, while inside the older stands, bats appear with greater diversity. From a bat conservation and forest management standpoint, the presence of mature pine forests is very important. Although the activity of all bats in mature stands was lower, they were important for closed-habitat foragers. Bats from this foraging guild include species from the genus Myotis and Barbastella, and these bats generally threatened or decreasing in Europe due to urbanization and simplification of forest structure associated with some silvicultural practices (Dietz et al. 2009). In addition, mature stands provide more shelters for bats (Brigham 2007; Burgar et al. 2015; Kalcounis-Rüppell et al. 2005). More opportunistic species in genera such as Pipistrellus, Nyctalus and Vespertilio tend to be increasing in numbers due to the increase in agricultural land, habitat fragmentation and urbanization (Jaberg and Guisan 2001; Johnson et al. 2008; WilliamsGuillén et al. 2016). Therefore, any mosaic of stand type must include mature stands evenly distributed throughout the landscape of managed pine.

\section{Conclusions}

- In clear-cut and young stands, there was higher bat activity, dominated by open-habitat foraging bats.

- In middle-aged and mature stands, there was relatively low activity but dominated by closed-habitat foragers.

- Management implications for pine stands are to maintain a mosaic of different growth stages of pine stands, which can support higher bat activity. From a bat conservation standpoint, the presence of mature forests might 
be important for closed-habitat foragers, including rare and threatened bat species. In addition, roost sites are critical for bats so it is important to maintain unmanaged old forest stands to recruit snags and other potential roost structures available to bats.

Acknowledgements This work was funded by the State Forests National Forest Holding, Poland [23/12]. Our thanks to all those involved in research: Jakub Górecki, Maurycy Ignaczak, Oktawiusz Iwanejko, Paweł Oleszkiewicz, Tomasz Rutkowski, Joanna Skonieczna, Wojciech Stephan, Michał Stopczyński, Rafał Szuflet, Urszula Turek and Dariusz Zjawiński. We also thank the employees of forest districts who helped in organizing field work. This manuscript was improved by the comments of careful reviewers.

Open Access This article is distributed under the terms of the Creative Commons Attribution 4.0 International License (http://creativeco mmons.org/licenses/by/4.0/), which permits unrestricted use, distribution, and reproduction in any medium, provided you give appropriate credit to the original author(s) and the source, provide a link to the Creative Commons license, and indicate if changes were made.

\section{References}

Adams MD, Law BS, French KO (2009) Vegetation structure influences the vertical stratification of open- and edge-space aerial-foraging bats in harvested forests. For Ecol Manag 258:2090-2100. https://doi.org/10.1016/j.foreco.2009.08.002

Ahlén I (1990) Identification of bats in flight. Swedish Society for Conservation of Nature \& Swedish Youth Association for Environmental Studies and Conservation, Stockholm

Ahlén I, Baagøe HJ (1999) Use of ultrasound detectors for bat studies in Europe: experiences from field identification, surveys, and monitoring. Acta Chiropterol 1:137-150

Ancillotto L, Cistrone L, Mosconi F, Jones G, Boitani L, Russo D (2015) The importance of non-forest landscapes for the conservation of forest bats: lessons from barbastelles (Barbastella barbastellus). Biodivers Conserv 24:171-185. https://doi.org/10.1007/ s10531-014-0802-7

Baagøe HJ (1987) The Scandinavian bat fauna: adaptive wing morphology, and free flight in the field. In: Fenton MB, Racey PA, Rayner JMV (eds) Recent advances in the study of bats. Cambridge University Press, Cambridge, pp 57-74

Barataud M (2015) Acoustic ecology of European bats. Species identification and studies of their habitats and foraging behaviour. Biotope Editions, Mèze; National Museum of Natural History, Paris

Bender MJ, Castleberry SB, Miller DA, Bently Wigley T (2015) Site occupancy of foraging bats on landscapes of managed pine forest. For Ecol Manag 336:1-10. https://doi.org/10.1016/j.forec o.2014.10.004

Böhm SM, Wells K, Kalko EKV (2011) Top-down control of herbivory by birds and bats in the canopy of temperate broad-leaved oaks (Quercus robur). PLoS ONE. https://doi.org/10.1371/journ al.pone.0017857

Borkin KM, Parsons S (2014) Effects of clear-fell harvest on bat home range. PLoS ONE. https://doi.org/10.1371/journal.pone.0086163

Brigham RM (2007) Bats in forests: what we know and what we need to learn. In: Lacki MJ, Hayes JP, Kurta A (eds) Bats in forests: conservation and management. Johns Hopkins University Press, Baltimore, pp 1-15
Brooks R (2009) Habitat-associated and temporal patterns of bat activity in a diverse forest landscape of southern New England, USA. Biodivers Conserv 18:529-545. https://doi.org/10.1007/s 1053 1-008-9518-x

Brooks RT, Ford WM (2005) Bat activity in a forest landscape of Central Massachusetts. Northeast Nat 12:447-462. https ://doi.org/10.1656/1092-6194(2005)012\%5b0447:BAIAF $\mathrm{L} \% 5 \mathrm{~d} 2.0 . \mathrm{CO} ; 2$

Burgar JM, Craig MD, Stokes VL (2015) The importance of mature forest as bat roosting habitat within a production landscape. For Ecol Manag 356:112-123. https://doi.org/10.1016/j.forec o.2015.07.027

Charbonnier Y, Barbaro L, Theillout A, Jactel H (2014) Numerical and functional responses of forest bats to a major insect pest in pine plantations. PLoS ONE. https://doi.org/10.1371/journ al.pone. 0109488

Ciechanowski M (2005) Utilization of artificial shelters by bats (Chiroptera) in three different types of forest. Folia Zool 54:31-37

Ciechanowski M (2015) Habitat preferences of bats in anthropogenically altered, mosaic landscapes of northern Poland. Eur J Wildl Res 61:415-428. https://doi.org/10.1007/s10344-015-0911-y

Ciechanowski M, Zając T, Biłas A, Dunajski R (2007) Spatiotemporal variation in activity of bat species differing in hunting tactics: effects of weather, moonlight, food abundance, and structural clutter. Can J Zool 85:1249-1263. https://doi.org/10.1139/z07-090

Core Team R (2018) R: a language and environment for statistical computing. R Foundation for Statistical Computing, Vienna

Crampton LH, Barclay RMR (1998) Selection of roosting and foraging habitat by bats in different-aged aspen mixedwood stands. Conserv Biol 12:1347-1358. https://doi.org/10.104 6/j.1523-1739.1998.97209.x

Dietz C, von Helversen O, Nill D (2009) Bats of Britain. A \& C Black, London

Dodd LE, Lacki MJ, Rieske LK (2008) Variation in moth occurrence and implications for foraging habitat of Ozark big-eared bats. For Ecol Manag 255:3866-3872. https://doi.org/10.1016/j.forec o.2008.03.034

Dodd LE et al (2012) Forest structure affects trophic linkages: how silvicultural disturbance impacts bats and their insect prey. For Ecol Manag 267:262-270. https://doi.org/10.1016/j.foreco.2011.12.016

Elmore LW, Miller DA, Vilella FJ (2005) Foraging area size and habitat use by red bats (Lasiurus borealis) in an intensively managed pine landscape in Mississippi. Am Midl Nat 153:405-417. https://doi.org/10.1674/0003-0031(2005)153\%5b0405:fasah $\mathrm{u} \% 5 \mathrm{~d} 2.0 . \mathrm{co} ; 2$

Erickson JL, West SD (2003) Associations of bats with local structure and landscape features of forested stands in western Oregon and Washington. Biol Conserv 109:95-102. https://doi.org/10.1016/ s0006-3207(02)00141-6

Ethier K, Fahrig L (2011) Positive effects of forest fragmentation, independent of forest amount, on bat abundance in eastern Ontario, Canada. Landsc Ecol 26:865-876. https://doi.org/10.1007/s1098 0-011-9614-2

Faber-Langendoen D et al (2016) Classification and description of world formation types. United States Department of Agriculture, Forest Service, Rocky Mountain Research Station

Fox J, Weisberg S (2011) An R companion to applied regression, 2nd edn. Sage, Thousand Oaks

Froidevaux JSP, Zellweger F, Bollmann K, Obrist MK (2014) Optimizing passive acoustic sampling of bats in forests. Ecol Evolut 4:4690-4700. https://doi.org/10.1002/ece3.1296

Grindal SD, Brigham RM (1999) Impacts of forest harvesting on habitat use by foraging insectivorous bats at different spatial scales. Ecoscience 6:25-34

GUS (2017) Forestry. Central Statistical Office, Warsaw 
Hein CD, Castleberry SB, Miller KV (2009) Site-occupancy of bats in relation to forested corridors. For Ecol Manag 257:1200-1207. https://doi.org/10.1016/j.foreco.2008.09.054

Hogberg LK, Patriquin KJ, Barclay RMR (2002) Use by bats of patches of residual trees in logged areas of the Boreal forest. Am Midl Nat 148:282-288. https://doi.org/10.1674/00030031(2002)148\%5b0282:ubbopo\%5d2.0.co;2

Humes ML, Hayes JP, Collopy MW (1999) Bat activity in thinned, unthinned, and old-growth forests in Western Oregon. J Wildl Manag 63:553-561. https://doi.org/10.2307/3802642

Jaberg C, Guisan A (2001) Modelling the distribution of bats in relation to landscape structure in a temperate mountain environment. J Appl Ecol 38:1169-1181. https://doi.org/10.104 6/j.0021-8901.2001.00668.x

Johnson JB, Gates JE, Ford WM (2008) Distribution and activity of bats at local and landscape scales within a rural-urban gradient. Urban Ecosyst 11:227-242. https://doi.org/10.1007/s1125 2-008-0055-x

Jung K, Kaiser S, Böhm S, Nieschulze J, Kalko EKV (2012) Moving in three dimensions: effects of structural complexity on occurrence and activity of insectivorous bats in managed forest stands. J Appl Ecol 49:523-531. https://doi.org/10.111 1/j.1365-2664.2012.02116.x

Kalcounis MC, Brigham RM (1995) Intraspecific variation in wing loading affects habitat use by little brown bats (Myotis lucifugus). Can J Zool 73:89-95. https://doi.org/10.1139/z95-011

Kalcounis MC, Hobson KA, Brigham RM, Hecker KR (1999) Bat activity in the boreal forest: importance of stand type and vertical strata. J Mammal 80:673-682. https://doi.org/10.2307/1383311

Kalcounis-Rüppell MC, Psyllakis JM, Brigham RM (2005) Tree roost selection by bats: an empirical synthesis using meta-analysis. Wildl Soc Bull 33:1123-1132. https://doi.org/10.2193/00917648(2005)33\%5b1123:trsbba\%5d2.0.co;2

Kalcounis-Rüppell MC, Briones KM, Homyack JA, Petric R, Marshall MM, Miller DA (2013) Hard forest edges act as conduits, not filters, for bats. Wildl Soc Bull 37:571-576. https://doi.org/10.1002/ wsb. 289

Kalko EKV, Schnitzler HU (1993) Plasticity in echolocation signals of European pipistrelle bats in search flight: implications for habitat use and prey detection. Behav Ecol Sociobiol 33:415-428. https ://doi.org/10.1007/BF00170257

Kasprzyk K, Ruczyński I (2001) The structure of bat communities roosting in bird nest boxes in two pine monocultures in Poland. Folia Zool 50:107-116

Kirkpatrick L, Maher SJ, Lopez Z, Lintott PR, Bailey SA, Dent D, Park KJ (2017) Bat use of commercial coniferous plantations at multiple spatial scales: management and conservation implications. Biol Cons 206:1-10. https://doi.org/10.1016/j.biocon.2016.11.018

Kożuchowski K (2011) Klimat Polski. Nowe spojrzenie. Wydawnictwo Naukowe PWN, Warszawa

Kruk H, Kornatowska B (2014) Sustainable forest management in Poland-theory and practice. Folia For Pol 56:45. https://doi. org/10.2478/ffp-2014-0005

Kusch J, Weber C, Idelberger S, Koob T (2004) Foraging habitat preferences of bats in relation to food supply and spatial vegetation structures in a western European low mountain range forest. Folia Zool 53:113-128

Lacki MJ, Johnson JS, Dodd LE, Baker MD (2007) Prey consumption of insectivorous bats in coniferous forests of north-central Idaho. Northwest Sci 81:199-205

Lacki MJ, Cox DR, Dodd LE, Dickinson MB (2009) Response of northern bats (Myotis septentrionalis) to prescribed fires in eastern Kentucky forests. J Mammal 90:1165-1175. https://doi. org/10.1644/08-mamm-a-349.1
Lenth R (2018) EMMEANS: estimated marginal means, aka leastsquares means. R package version 1.2.3. https://cran.r-project.org/ package=emmeans. Accessed 12 Sept 2018

Loeb SC, O'Keefe JM (2006) Habitat use by forest bats in South Carolina in relation to local, stand, and landscape characteristics. J Wildl Manag 70:1210-1218. https://doi.org/10.2193/0022$541 \times(2006) 70 \% 5$ b1210:hubfbi\%5d2.0.co;2

Loeb SC, Waldrop TA (2008) Bat activity in relation to fire and fire surrogate treatments in southern pine stands. For Ecol Manag 255:3185-3192. https://doi.org/10.1016/j.foreco.2007.10.060

Lunde RE, Harestad AS (1986) Activity of little brown bats in coastal forests. Northwest Sci 60:206-209

Maier C (1992) Activity patterns of pipistrelle bats (Pipistrellus pipistrellus) in Oxfordshire. J Zool 228:69-80

McCarthy N, Bentsen NS, Willoughby I, Balandier P (2011) The state of forest vegetation management in Europe in the 21st century. Eur J For Res 130:7-16. https://doi.org/10.1007/s10342-010-0429-5

McDermott CL, Cashore B, Kanowski P (2010) Global environmental forest policies: an international comparison. Earthscan, London

Mehr M, Brandl R, Hothorn T, Dziock F, Förster B, Müller J (2011) Land use is more important than climate for species richness and composition of bat assemblages on a regional scale. Mamm Biol 76:451-460. https://doi.org/10.1016/j.mambio.2010.09.004

Mehr M, Brandl R, Kneib T, Müller J (2012) The effect of bark beetle infestation and salvage logging on bat activity in a national park. Biodivers Conserv 21:2775-2786. https://doi.org/10.1007/s1053 1-012-0334-y

Menzel MA, Carter TC, Ford WM, Chapman BR (2001) Tree-roost characteristics of subadult and female adult evening bats $(\mathrm{Nyc}$ ticeius humeralis) in the Upper Coastal Plain of South Carolina. Am Midl Nat 145:112-119. https://doi.org/10.1674/00030031(2001)145\%5b0112:trcosa\%5d2.0.co;2

Menzel MA, Carter TC, Menzel JM, Ford WM, Chapman BR (2002) Effects of group selection silviculture in bottomland hardwoods on the spatial activity patterns of bats. For Ecol Manag 162:209-218. https://doi.org/10.1016/s0378-1127(01)00516-3

Menzel JM, Menzel MA, Kilgo JC, Ford WM, Edwards JW, McCracken GF (2005) Effect of habitat and foraging height on bat activity in the Coastal Plain of South Carolina. J Wildl Manag 69:235-245. https://doi.org/10.2193/0022-541x(2005)069\%3c023 5:eohafh\%3e2.0.co;2

Miles AC, Castleberry SB, Miller DA, Conner LM (2006) Multiscale roost-site selection by evening bats on pine-dominated landscapes in southwest Georgia. J Wildl Manag 70:1191-1199. https://doi.org/10.2193/0022-541x(2006)70\%5b1191:mrsbe b\% $5 \mathrm{~d} 2.0 . \mathrm{co} ; 2$

Miller DA (2003) Species diversity, reproduction, and sex ratios of bats in managed pine forest landscapes of Mississippi. Southeast Nat 2:59-72. https://doi.org/10.1656/1528-7092(2003)002\%5b005 9:sdrasr\%5d2.0.co;2

Mills SC, Adams AM, Phoenix RD (2013) Bat species diversity in the boreal forest of Northeastern Ontario, Canada. Northeast Nat 20:309-324. https://doi.org/10.1656/045.020.0207

Morris AD, Miller DA, Kalcounis-Rüppell MC (2010) Use of forest edges by bats in a managed pine forest landscape. J Wildl Manag 74:26-34. https://doi.org/10.2193/2008-471

Müller J et al (2012) Aggregative response in bats: prey abundance versus habitat. Oecologia 169:673-684. https://doi.org/10.1007/ s00442-011-2247-y

Müller J et al (2013) From ground to above canopy—bat activity in mature forests is driven by vegetation density and height. For Ecol Manag 306:179-184. https://doi.org/10.1016/j.foreco.2013.06.043

Nyholm ES (1965) Zur Ökologie von Myotis mystacinus (Leisl.) und Myotis daubentoni (Leisl.) (Chiroptera). Annales Zoologici Fennici 2:77-123 
O'Hara RB, Kotze DJ (2010) Do not log-transform count data. Methods Ecol Evolution 1:118-122. https://doi.org/10.1111/j.2041210X.2010.00021.x

Owen SF, Menzel MA, Ford WM, Chapman BR, Miller KV, Edwards JW, Wood PB (2003) Home-range size and habitat used by the northern myotis (Myotis septentrionalis). Am Midl Nat 150:352359. https://doi.org/10.1674/0003-0031(2003)150\%5b0352:hsahu b\% $5 \mathrm{~d} 2.0 . \mathrm{co} ; 2$

Owen SF et al (2004) Bat activity in harvested and intact forest stands in the Allegheny Mountains. North J Appl For 21:154-159

Patriquin KJ, Barclay RMR (2003) Foraging by bats in cleared, thinned and unharvested boreal forest. J Appl Ecol 40:646-657. https:// doi.org/10.1046/j.1365-2664.2003.00831.x

Perry RW, Thill RE, Leslie DM Jr (2008) Scale-dependent effects of landscape structure and composition on diurnal roost selection by forest bats. J Wildl Manag 72:913-925. https://doi. org/10.2193/2006-435

Plank M, Fiedler K, Reiter G (2012) Use of forest strata by bats in temperate forests. J Zool 286:154-162. https://doi.org/10.111 1/j.1469-7998.2011.00859.x

Rachwald A (1992) Habitat preference and activity of the noctule bat Nyctalus noctula in the Bialowieza Primeval Forest. Acta Theriol 37:413-422

Rodriguez-San Pedro A, Simonetti JA (2015) Does understory clutter reduce bat activity in forestry pine plantations? Eur J Wildl Res 61:177-179. https://doi.org/10.1007/s10344-014-0871-7

Russ JM, Montgomery WI (2002) Habitat associations of bats in Northern Ireland: implications for conservation. Biol Conserv 108:49-58. https://doi.org/10.1016/S0006-3207(02)00089-7

Russ JM, Briffa M, Montgomery WI (2003) Seasonal patterns in activity and habitat use by bats (Pipistrellus spp. and Nyctalus leisleri) in Northern Ireland, determined using a driven transect. J Zool 259:289-299. https://doi.org/10.1017/s0952836902003254

Russo D, Jones G (2003) Use of foraging habitats by bats in a Mediterranean area determined by acoustic surveys: conservation implications. Ecography 26:197-209. https://doi.org/10.103 4/j.1600-0587.2003.03422.x

Rydell J (1989) Feeding activity of the northern bat Eptesicus nilssoni during pregnancy and lactation. Oecologia 80:562-565. https:// doi.org/10.1007/bf00380082

Rydell J, Nyman S, Eklöf J, Jones G, Russo D (2017) Testing the performances of automated identification of bat echolocation calls: a request for prudence. Ecol Ind 78:416-420. https://doi. org/10.1016/j.ecolind.2017.03.023

Sachanowicz K, Ciechanowski M, Piksa K (2006) Distribution patterns, species richness and status of bats in Poland. Vespertilio 9-10:151-173

Schmitt CB et al (2009) Global ecological forest classification and forest protected area gap analysis. Analyses and recommendations in view of the $10 \%$ target for forest protection under the Convention on Biological Diversity (CBD), 2nd edn. Freiburg University Press, Freiburg

Schnitzler HU, Kalko EKV (2001) Echolocation by insect-eating bats. Bioscience 51:557-569. https://doi.org/10.1641/00063568(2001)051\%5b0557:ebieb\%5d2.0.co;2
Schnitzler HU, Moss CF, Denzinger A (2003) From spatial orientation to food acquisition in echolocating bats. Trends Ecol Evol 18:386-394. https://doi.org/10.1016/s0169-5347(03)00185-x

Siemers BM, Schnitzler HU (2004) Echolocation signals reflect niche differentiation in five sympatric congeneric bat species. Nature 429:657-661. https://doi.org/10.1038/nature02547

Skiba R (2003) Europäische Fledermäuse. Kennzeichen, Echoortung und Detektoranwendung. Neue Brehm-Bücherei Band 648, Westarp Wissenschaften

Thomas DW (1988) The distribution of bats in different ages of Douglas-fir forest. J Wildl Manag 52:619-626

Tibbels AE, Kurta A (2003) Bat activity is low in thinned and unthinned stands of red pine. Can J For Res 33:2436-2442. https ://doi.org/10.1139/x03-177

Titchenell MA, Williams RA, Gehrt SD (2011) Bat response to shelterwood harvests and forest structure in oak-hickory forests. For Ecol Manag 262:980-988. https://doi.org/10.1016/j.foreco.2011.05.032

Vaughan N, Jones G, Harris S (1997) Identification of British bat species by multivariate analysis of echolocation call parameters. Bioacoustics 7:189-207

Venables WN, Ripley BD (2002) Modern applied statistics with S, 4th edn. Springer, New York

Vindigni MA, Morris AD, Miller DA, Kalcounis-Rüppell MC (2009) Use of modified water sources by bats in a managed pine landscape. For Ecol Manag 258:2056-2061. https://doi.org/10.1016/j. foreco.2009.07.058

Warton DI, Lyons M, Stoklosa J, Ives AR, Schielzeth H (2016) Three points to consider when choosing a LM or GLM test for count data. Methods Ecol Evolut 7:882-890. https://doi. org/10.1111/2041-210X.12552

Wermundsen T, Siivonen Y (2008) Foraging habitats of bats in southern Finland. Acta Theriol 53:229-240. https://doi.org/10.1007/ bf03193119

Williams-Guillén K, Olimpi E, Maas B, Taylor PJ, Arlettaz R (2016) Bats in the anthropogenic matrix: challenges and opportunities for the conservation of Chiroptera and their ecosystem services in agricultural landscapes. In: Voigt CC, Kingston T (eds) Bats in the Anthropocene: conservation of bats in a changing world. Springer International Publishing, Cham, pp 151-186. https://doi. org/10.1007/978-3-319-25220-9_6

Yates MD, Muzika RM (2006) Effect of forest structure and fragmentation on site occupancy of bat species in Missouri ozark forests. J Wildl Manag 70:1238-1248. https://doi.org/10.2193/0022$541 \mathrm{x}(2006) 70 \% 5 \mathrm{~b} 1238$ :eofsaf\% $5 \mathrm{~d} 2.0 . \mathrm{co} ; 2$

Zeileis A, Kleiber C, Jackman S (2008) Regression models for count data in R. J Stat Softw 27:1-25. https://doi.org/10.18637/jss.v027. i08

Publisher's Note Springer Nature remains neutral with regard to jurisdictional claims in published maps and institutional affiliations. 